\title{
INFLUENCE OF DIFFERENT THERMAL ENVIRONMENTS ON THE PERFORMANCE OF LAYING HENS DURING THE INITIAL STAGE OF REARING
}

\author{
Rafaella R. Andrade ${ }^{1 *}$, Ilda de F. F. Tinôco², Fernando da C. Baêta², Luiz F. T. Albino², \\ Paulo R. Cecon ${ }^{2}$
}

\begin{abstract}
${ }^{1 *}$ Corresponding author. Federal University of Viçosa/ Viçosa - MG, Brazil. E-mail: rafaella_resende2@hotmail.com ORCID ID: https://orcid.org/0000-0003-3182-0741
\end{abstract}

\section{KEYWORDS}

ambience, zootechnical performance, cold stress, light laying hens, thermoneutrality

\begin{abstract}
This study was conducted with the aim of assessing the effects of different ambient temperature values on the performance of laying birds from one to 42 days of age in order to obtain optimal comfort temperatures. A total of 864 laying hens were distributed in four climatic chambers with different temperature ranges. One of the chambers was maintained within the thermal range recommended by the literature and the others were maintained under temperatures that consisted of mild and moderate cold stress and moderate heat stress. The experiment was conducted according to a completely randomized design in a split-plot arrangement and six replications. The data were analyzed by means of the analysis of variance and regression. The final performance of birds with temperatures of $33,28,26,23,19$, and $19^{\circ} \mathrm{C}$ (for the first, second, third, fourth, fifth, and sixth week of age, respectively) presented better productive results, confirming the assertiveness regarding the best thermal comfort and welfare of laying birds during the rearing stage. The results showed that under conditions of cold thermal stress, birds presented a worse performance, thus affecting their development and productive efficiency.
\end{abstract}

\section{INTRODUCTION}

The significant development of the Brazilian poultry industry allowed an expressive increase in egg production, placing it as one of the main agricultural activities of the country and providing to the consumer a protein source at reduced costs. The expressive increase in egg production per hen is mainly due to the highly intensive agricultural systems, optimized nutrition, and breeding of laying birds with the aim of promoting fast growth speed and high egg production (Regmi et al., 2015).

Similarly to broiler chickens, the initial stage of rearing of laying hens requires special care in relation to the environment, management, and nutrition considering the good development and non-compromise of pullet quality and, consequently, productivity of the laying bird. The greatest variations of weight and development of organs and all tissues occur during the rearing stage and the complete and adequate organ formation must occur within five to six weeks of age. However, the physiological system is still under development, both anatomically and functionally (Albino et al., 2014).

Regarding housing, laying birds should be protected from very low temperatures or even from sudden changes in temperature during their initial stages of growth, which is a major problem for open poultry sheds and without controlled environments, as is the case of almost all constructions for laying birds in Brazil.

The best animal productivity is reached when they are kept under a thermoneutral environment, i.e. when food energy is not diverted to eliminate or maintain its heat (Curi et al., 2014; Lopes et al., 2015; Ponciano et al., 2011).

Usually, thermoneutral limits are set in indirect measures such as air temperature, relative humidity, ventilation, among other environmental variables (Schiassi et al., 2015). The facility should promote a comfortable environment for the animal without requiring the expenditure of energy conservation or heat dissipation and avoiding negative thermal effects on the production (Almeida \& Passini, 2013; Campos et al., 2013; Santos et al., 2014).

Animal welfare is the full state of physical and mental health in which the animal is in harmony with the environment where it lives (Camerini et al., 2016). When submitted to cold stress, bird seeks to maintain homeothermia by increasing heat production and reducing

\footnotetext{
${ }^{2}$ Federal University of Viçosa/ Viçosa - MG, Brazil.

Received in: 8-21-2018

Accepted in: 12-7-2018
} 
losses, while in a situation of heat stress the process occurs inversely (Costa et al., 2012). In the first days of life, bird temperature should be between 33 to $34{ }^{\circ} \mathrm{C}$ (Menegali et al., 2013).

Therefore, for the Brazilian climate conditions, there is a need for supplementary heating during the initial stage of the life of birds because they are sensitive to cold. Considering that, it is observed that the ambient temperature is a major factor on bird performance, especially on the young ones, which, when maintained under an ideal temperature range, have a predominance of minimum metabolic rates, not occurring deviation of nutrients to maintain body temperature, which contributes to the expression of their genetic potential. Hence the importance of seeking to ensure, through conditioning, an appropriate environment within rearing accommodation.

Therefore, even knowing the importance of the thermal environment for bird rearing, studies on ideal rearing temperatures and their effects on laying birds during the initial stage are scarce in the literature, when birds are more vulnerable to problems related to cold and can affect the future stages of life (rearing and laying), which justifies the present study.

The aim of this study was to determine the comfort temperature and assess the effect of different temperatures (assessed in terms of air temperature and black globe temperature and humidity index, BGHI) on laying birds in the initial stage of rearing, leading to a better productive performance.

\section{MATERIAL AND METHODS}

The experiment was developed in four climatic chambers (Figures 1A and 1B) with dimensions of $3.2 \mathrm{~m}$ long $\times 2.44 \mathrm{~m}$ wide $\times 2.38$ high and located in the experimental area of the Research Nucleus in Ambience and Engineering of Agroindustrial Systems (AMBIAGRO) of the Sector of Rural Constructions and Ambience of the Department of Agricultural Engineering of the Federal University of Viçosa, Viçosa, Minas Gerais, Brazil.
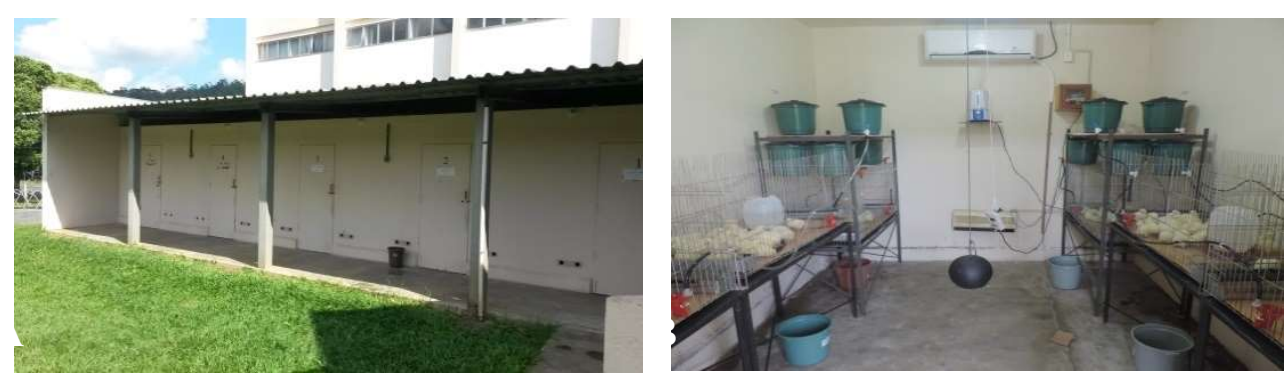

FIGURE 1. A) External view of the climatic chambers. B) Internal view of one of the climatic chambers.

Viçosa is located at the geographical coordinates $20^{\circ} 46^{\prime} 17^{\prime \prime} \mathrm{S}$ and $42^{\circ} 52^{\prime} 21^{\prime \prime} \mathrm{W}$, in a region with an average altitude of $670 \mathrm{~m}$ and a climate characterized by a cold and dry winter and warm and humid summer according to Köppen classification.

Each climate chamber is equipped with an electric resistance air heater with $2000 \mathrm{~W}$ of power, a hot/cold split air conditioner of $3,500 \mathrm{~W}$, and an air humidifier with a $4.5 \mathrm{~L}$ capacity and fog flow (average value) of $300 \mathrm{~mL}$ per hour. The heater and humidifier were operated by means of an MT-531R Plus electronic controller of temperature and humidity that has as specifications a control temperature ranging from -10 to $70{ }^{\circ} \mathrm{C}$ with a $0.1{ }^{\circ} \mathrm{C}$ resolution and control humidity ranging from 20 to $85 \%$ with a $0.1 \%$ resolution.

The facility also had two AMB axial fans (model FD08025 S1M; DC $12 \mathrm{~V}, 0.15 \mathrm{~A})$ responsible for the hygienic air renewal, which provided from 3 to 6 renovations per hour inside the climatic chambers during the whole experimental period.

The concentrations of ammonia $\left(\mathrm{NH}_{3}\right)$ and carbon dioxide $\left(\mathrm{CO}_{2}\right)$ inside the climatic chambers were monitored throughout the experimental period in order to ensure adequate air quality conditions inside them.

Four different thermal environments were established at each of the four climatic chambers, consisting of the following treatments: comfort recommended by the literature (Management Guide Lohmann LSL Lite, s.d.; Albino et al., 2014), mild and moderate cold stress, and moderate heat stress. Considering that the thermal requirement of bird varies with age, we sought to represent it in each week of bird life during the experimental period. The variation of the weekly temperature occurred until the fifth week and the sixth week remained with a temperature similar to that observed in the fifth week. Table 1 shows the different temperatures used in this study.

TABLE 1. Air temperature $\left({ }^{\circ} \mathrm{C}\right)$ in the internal environment of the climatic chambers as a function of the treatments moderate heat $(\mathrm{MoH})$, recommended comfort $(\mathrm{ReC})$, mild cold $(\mathrm{MiC})$, and moderate cold $(\mathrm{MoC})$ and weeks of age of laying hens of the Lohmann LSL Lite strain from one to 42 days.

\begin{tabular}{lccccc}
\hline \multicolumn{1}{c}{ Treatments } & \multicolumn{5}{c}{ Temperature $\left({ }^{\circ} \mathrm{C}\right)$} \\
\cline { 2 - 6 } & $1^{\text {st }}$ week & $2^{\text {nd }}$ week & $3^{\text {rd }}$ week & $4^{\text {th }}$ week & $5^{\text {th }}$ and $6^{\text {th }}$ weeks \\
\hline Moderate heat $(\mathrm{MoH})$ & 38 & 31 & 29 & 26 & 22 \\
Recommended comfort (ReC) & 33 & 28 & 26 & 23 & 19 \\
Mild cold (MiC) & 28 & 25 & 23 & 20 & 17 \\
Moderate cold (MoC) & 25 & 22 & 20 & $17^{*}$ & $17^{*}$ \\
\hline
\end{tabular}

Source: Adapted from Management Guide Lohmann LSL Lite (s.d.) and Albino et al. (2014); *There was the need to work with a minimum temperature obtained in the chambers of $17^{\circ} \mathrm{C}$. 
The relative air humidity was monitored and the values were maintained around $60 \%$ (range of 55 to $65 \%$ ) throughout the experimental period for all treatments since it is considered an adequate value for poultry production regardless of the bird age (Tinôco, 2001). The values of air temperature $\left(\mathrm{T}_{\text {air }}\right)$, air relative humidity $(\mathrm{RH})$, and black globe temperature $\left(\mathrm{T}_{\mathrm{bg}}\right)$ were recorded every 5 minutes, 24 hours a day, throughout the experimental period.

$\mathrm{T}_{\text {air }}$ and $\mathrm{RH}$ were measured with $\mathrm{HOBO}^{\circledR} \mathrm{T} / \mathrm{RH}$ data loggers model U14-001 ( -20 to $\left.+70{ }^{\circ} \mathrm{C}\right)$, with a 0.7 ${ }^{\circ} \mathrm{C}$ accuracy. In order to obtain $\mathrm{T}_{\mathrm{bg}}$, a black globe was installed inside each climatic chamber, inside which a Testo temperature recorder sensor model 174 , with a 0.1 ${ }^{\circ} \mathrm{C}$ resolution, measuring range from -30 to $70{ }^{\circ} \mathrm{C}$, and accuracy of $\pm 0.5{ }^{\circ} \mathrm{C}$ was placed. The sensors were installed at the bird height in the center of each climatic chamber. The black globe temperature and humidity index (BGHI) was calculated from the collected data of the climatic variables using the [eq. (1)], as proposed by Buffington et al. (1981).

$$
\mathrm{BGHI}=\mathrm{T}_{\mathrm{bg}}+0.36 \mathrm{~T}_{\mathrm{dp}}+41.5
$$

Where,

$\mathrm{T}_{\mathrm{bg}}$ is the black globe temperature $\left({ }^{\circ} \mathrm{C}\right)$, and

$\mathrm{T}_{\mathrm{dp}}$ is the dew point temperature $\left({ }^{\circ} \mathrm{C}\right)$.

All procedures adopted in this experiment were approved by the Animal Ethics Committee (CEUA) of the Federal University of Viçosa (UFV), with registration protocol No. 45/2016.

The experiment was carried out with birds of the same age, origin, and uniform weight from one to 42 days of age, which is considered the rearing stage for laying birds. This period is characterized by the need to heat the rearing environment to obtain the values of temperature required by the birds, known as the heating period, in which bird does not yet have a fully formed thermoregulator system.

During the experimental period, 864 laying hens of the Lohmann LSL Lite line, with an average initial weight of $41.53 \mathrm{~g}$, homogeneously distributed in four climatic chambers (four treatments), totaling 216 birds per treatment, were housed in cages. The cages had $0.50 \mathrm{~m}^{2}$ in area $(0.50 \mathrm{~m}$ wide $\times 1.0 \mathrm{~m}$ long $)$ and $0.5 \mathrm{~m}$ high, being six units per chamber and six replications per treatment, with each treatment consisting of different temperatures.

Before the beginning of the experimental period, the birds were standardized in the treatments regarding similar body weight and the same age and origin. From the first day to the end of the fourth week, each cage housed 36 chicks in order to guarantee a density of $140 \mathrm{~cm}^{2} \mathrm{bird}^{-1}$. From the beginning of the fifth week until the end of the sixth week, a density of $285 \mathrm{~cm}^{2}$ bird $^{-1}$ was used, which corresponds to 18 birds per cage (Management Guide Lohmann LSL Lite, s.d.). This procedure was adopted to guarantee the density used by the poultry industry under field conditions for each of the different ages.

For the period from one to 42 days of age of birds, water and food were supplied ad libitum daily twice a day (at 7:00 and 17:00 h) in order to maintain stocked drinking and feeding troughs. The diets were formulated according to Rostagno et al. (2011) based on nutrient requirements for the different growth stages, being the same for all treatments.

For the data related to animal performance, the following results were assessed weekly: body weight (BW, in grams), in which all birds were weighed and randomly distributed among the cages on the first experimental day, being then weighed at the end of each experimental week; weight gain (WG, in grams), in which the weight of birds was recorded at the end of each experimental week and made the difference in relation to that of the previous week; feed intake (FI, in grams), calculated daily from the difference between the feed supplied and the leftovers available in the feeding troughs, being calculated the average amount of feed consymed in each replication at the end of each week; feed conversion (FC), obtained by the relationship between feed intake in grams and weight gain in grams; and uniformity ( $U$, in $\%$ ), calculated based on the average lot weight, from which a variation of weight was determined with a tolerance of ten percent above and below. In this case, each bird was individually weighed to determine the percentage of birds within this range, which represented the average lot weight.

The experiment was conducted in a completely randomized design in a split-plot arrangement with four treatments (moderate heat, comfort recommended by the Lohmann LSL Lite Manual, mild cold, and moderate cold) in the plots and assessments (days) in the subplots, with six replications. The data were analyzed through the analysis of variance and regression. For the qualitative factor, means were compared by the Tukey's test at 5\% probability level. For the quantitative factor, the regression analysis was used and models were chosen according to the significance of regression coefficients, using the t-test at $10 \%$ probability level in the coefficient of determination $\left(\mathrm{R}^{2}=\mathrm{SQ}\right.$ Regression/SQ Treatment) and in the behavior of the phenomenon under study.

Regardless of whether or not the interaction is significant, we chose to slice it because of the interest in the study. The results were statistically interpreted using the software Sistema para Análises Estatísticas e Genética (SAEG, 2007).

\section{RESULTS AND DISCUSSION}

\section{Rearing environment}

The average values of air temperature $\left(\mathrm{T}_{\text {air }}\right)$, relative air humidity (RH), and black globe temperature and humidity index (BGHI), corresponding to each thermal environment, are shown in Table 2. 
TABLE 2. Means and standard deviations of $\mathrm{T}_{\text {air }}$, RH, and BGHI for each assessed climatic condition (moderate heat, recommended comfort, mild cold, and moderate cold) in the period from one to 42 days of life of laying birds.

\begin{tabular}{|c|c|c|c|}
\hline Thermal environment & $\mathbf{T}_{\text {air }}\left({ }^{\circ} \mathbf{C}\right)$ & RH (\%) & BGHI \\
\hline \multicolumn{4}{|c|}{ First week } \\
\hline Moderate heat $(\mathrm{MoH})$ & $37.9 \pm 0.2$ & $55.5 \pm 2.4$ & $89.0 \pm 1.5$ \\
\hline Recommended comfort (ReC) & $33.0 \pm 0.4$ & $56.5 \pm 1.2$ & $82.7 \pm 1.3$ \\
\hline Mild cold (MiC) & $28.0 \pm 0.3$ & $62.4 \pm 2.5$ & $76.3 \pm 0.5$ \\
\hline Moderate cold (MoC) & $25.0 \pm 0.2$ & $61.6 \pm 1.5$ & $72.3 \pm 0.5$ \\
\hline \multicolumn{4}{|c|}{ Second week } \\
\hline Moderate heat $(\mathrm{MoH})$ & $31.1 \pm 0.5$ & $60.1 \pm 2.0$ & $80.7 \pm 0.6$ \\
\hline Recommended comfort ( $\mathrm{ReC})$ & $28.2 \pm 0.5$ & $62.6 \pm 2.4$ & $76.9 \pm 0.8$ \\
\hline Mild cold (MiC) & $25.1 \pm 0.6$ & $63.1 \pm 1.5$ & $71.8 \pm 1.4$ \\
\hline Moderate cold (MoC) & $22.1 \pm 0.6$ & $62.9 \pm 2.0$ & $69.1 \pm 1.2$ \\
\hline \multicolumn{4}{|c|}{ Third week } \\
\hline Moderate heat (MoH) & $29.1 \pm 0.4$ & $61.1 \pm 2.2$ & $76.9 \pm 1.1$ \\
\hline Recommended comfort ( $\mathrm{ReC})$ & $26.0 \pm 0.5$ & $60.4 \pm 2.4$ & $72.4 \pm 0.9$ \\
\hline Mild cold (MiC) & $23.1 \pm 0.5$ & $60.9 \pm 0.2$ & $70.9 \pm 1.4$ \\
\hline Moderate cold (MoC) & $20.1 \pm 0.2$ & $64.1 \pm 0.8$ & $66.3 \pm 1.1$ \\
\hline \multicolumn{4}{|c|}{ Fourth week } \\
\hline Moderate heat $(\mathrm{MoH})$ & $26.0 \pm 0.6$ & $62.3 \pm 0.5$ & $73.8 \pm 1.0$ \\
\hline Recommended comfort (ReC) & $23.1 \pm 0.7$ & $62.8 \pm 0.7$ & $70.7 \pm 1.2$ \\
\hline Mild cold (MiC) & $20.1 \pm 0.5$ & $60.3 \pm 0.2$ & $66.3 \pm 0.8$ \\
\hline Moderate cold (MoC) & $17.0 \pm 0.5$ & $64.6 \pm 0.5$ & $63.6 \pm 0.6$ \\
\hline \multicolumn{4}{|c|}{ Fifth and sixth weeks } \\
\hline Moderate heat $(\mathrm{MoH})$ & $22.1 \pm 0.4$ & $64.6 \pm 0.2$ & $70.2 \pm 2.4$ \\
\hline Recommended comfort ( $\mathrm{ReC})$ & $19.2 \pm 0.5$ & $62.7 \pm 1.2$ & $66.4 \pm 1.3$ \\
\hline Mild cold (MiC) & $17.0 \pm 0.2$ & $64.5 \pm 0.5$ & $63.8 \pm 0.2$ \\
\hline Moderate cold (MoC) & $17.0 \pm 0.2$ & $64.2 \pm 1.3$ & $63.6 \pm 0.2$ \\
\hline
\end{tabular}

The average values of temperature and relative air humidity were maintained close to the values proposed for each thermal environment, indicating an adequate control of the environment inside the climatic chambers. The maintenance of the relative air humidity without large oscillations is essential for chick development (Jácome et al., 2007).

During the first and second weeks of experiment, the recommended comfort treatment was closer to the values found by Cella et al. (2001), who observed, as thermal comfort for broilers from 1 to 7 days, BGHI values of $81.6 \pm 0.59$ for the first week, $76.3 \pm 0.59$ for the second week, and $72.9 \pm 1.14$ for the third week. For the third experimental week, the recommended comfort and mild cold treatments tended to be closer to the BGHI values for thermal comfort.
Jácome et al. (2007) analyzed thermal comfort indices of laying bird chicks during the rearing stage in a shed covered with ceramic tile and found BGHI values ranging from 79.2 to 75.1 for their first weeks of life. These values were considered as below the comfort level, which indicates a failure in the heating of the chicks. A similar situation was found in this research throughout the experimental period for moderate cold treatment.

\section{Body weight}

Table 3 shows the values of body weight (BW) of Lohmann LSL Lite line chicks from one to 42 days of age submitted to the treatments moderate heat $(\mathrm{MoH})$, recommended comfort $(\mathrm{ReC})$, mild cold $(\mathrm{MiC})$, and moderate cold (MoC).

TABLE 3. Average values of body weight (BW) in grams for laying birds from one to 42 days of age for the respective combinations of days and the thermal environments moderate heat $(\mathrm{MoH})$, recommended comfort $(\mathrm{ReC})$, mild cold $(\mathrm{MiC})$, and moderate cold (MoC).

\begin{tabular}{|c|c|c|c|c|}
\hline \multirow{2}{*}{ Bird age } & \multicolumn{4}{|c|}{ BW } \\
\hline & МoH & ReC & $\mathrm{MiC}$ & MoC \\
\hline 1 & $43.23^{\mathrm{a}}$ & $42.34^{\mathrm{a}}$ & $39.68^{a}$ & $40.88^{a}$ \\
\hline 8 & $66.41^{\mathrm{a}}$ & $67.68^{a}$ & $64.58^{\mathrm{a}}$ & $64.30^{\mathrm{a}}$ \\
\hline 15 & $106.93^{\mathrm{a}}$ & $114.11^{\mathrm{a}}$ & $111.61^{\mathrm{a}}$ & $107.61^{\mathrm{a}}$ \\
\hline 22 & $179.44^{\mathrm{a}}$ & $185.75^{a}$ & $170.44^{\mathrm{a}}$ & $164.80^{\mathrm{a}}$ \\
\hline 29 & $265.93^{a}$ & $254.50^{\mathrm{a}}$ & $239.64^{\mathrm{a}}$ & $240.55^{a}$ \\
\hline 36 & $331.72^{a}$ & $348.22^{\mathrm{a}}$ & $320.06^{\mathrm{a}}$ & $324.70^{\mathrm{a}}$ \\
\hline 42 & $410.72^{a}$ & $430.42^{\mathrm{a}}$ & $409.44^{\mathrm{a}}$ & $411.68^{a}$ \\
\hline
\end{tabular}

Means followed by at least one letter in the row do not differ from each other by the Tukey's test at $5 \%$ probability level. 
The assessment of the zootechnical performance of birds submitted to different treatments and in relation to each assessed age showed that the initial body weight was equal, proving that the birds were standardized, discarding the possibility of a possible initial favoring in relation to some of the treatments.

Birds with 8, 22, 29, and 36 days of age presented the highest values of body weight for those submitted to the treatments moderate heat and recommended comfort. At 42 days of age, birds from the recommended comfort, submitted to an ambient temperature of $19.0{ }^{\circ} \mathrm{C}$, reached the highest average weight of $430.42 \mathrm{~g}$, being the only treatment to present a weight within the range considered as ideal for birds at the end of the rearing stage according to the line manual (Management Guide Lohmann LSL Lite, s.d.).

The regression analysis showed, for all treatments, a linear increase $(\mathrm{P}<0.01)$ in the age of laying birds in relation to body weight, i.e. the weight increased as the age of birds increased (Table 4 and Figure 2).

TABLE 4. Adjusted regression equations for the variable body weight (BW) of laying birds from one to 42 days of age as a function of the assessed days for the thermal environments moderate heat $(\mathrm{MoH})$, recommended comfort (ReC), mild cold $(\mathrm{MiC})$, and moderate cold $(\mathrm{MoC})$ and coefficients of determination.

\begin{tabular}{ccc}
\hline Thermal environment & Adjusted equations & $\mathbf{r}^{2}$ \\
\hline $\mathrm{MoH}$ & $\hat{\mathrm{Y}}=-12.1471+9.6092^{* *} \mathrm{D}$ & 0.9821 \\
$\mathrm{ReC}$ & $\hat{\mathrm{Y}}=-15.2720+9.9997^{* *} \mathrm{D}$ & 0.9793 \\
$\mathrm{MiC}$ & $\hat{\mathrm{Y}}=-13.7258+9.3649^{* *} \mathrm{D}$ & 0.9769 \\
$\mathrm{MoC}$ & $\hat{\mathrm{Y}}=-16.0789+9.4652^{* *} \mathrm{D}$ & 0.9726 \\
\hline
\end{tabular}

$* * \mathrm{P}<0.01$ by the $\mathrm{t}$-test.

$\mathrm{MoH} \quad \mathrm{Y}=-12.1471+9.6092 \mathrm{D}$

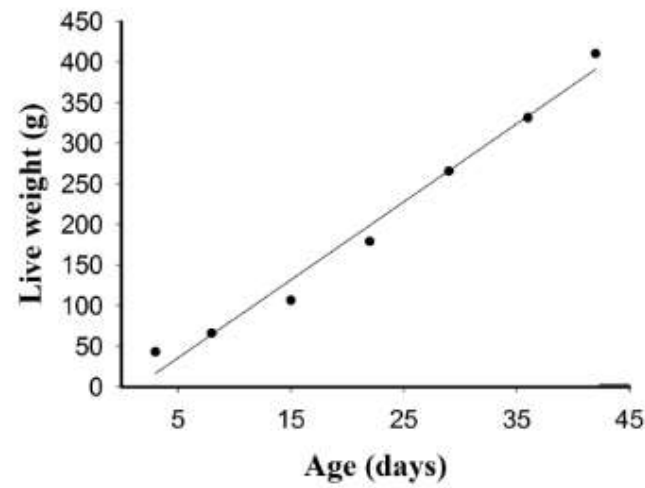

$\operatorname{MiC} \quad \mathrm{Y}=-13.7258+9.3649 \mathrm{D}$

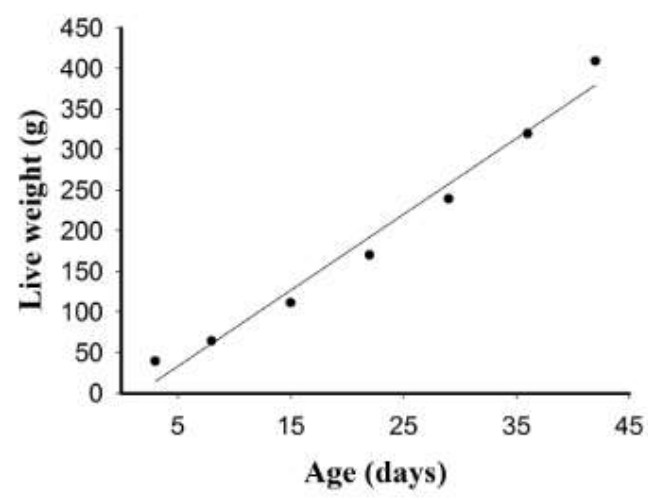

$\operatorname{ReC} \quad \mathrm{Y}=-15.2720+9.9997 \mathrm{D}$

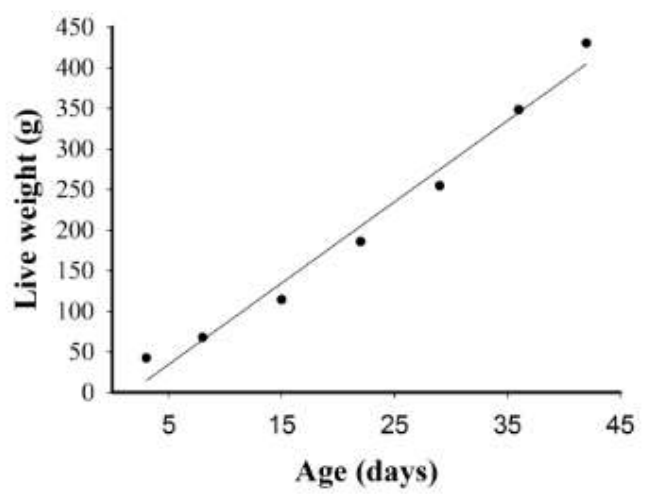

MoC $\quad \mathrm{Y}=-16.0789+9.4652 \mathrm{D}$

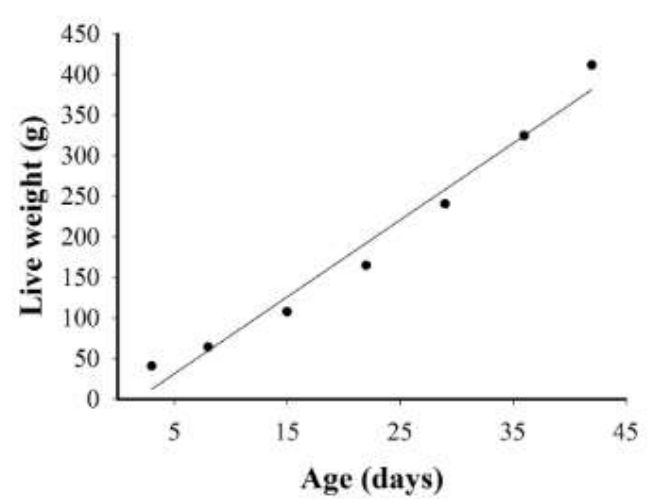

FIGURE 2. Effect of assessment days on live weight for each thermal environment assessed in laying birds from one to 42 days. MoH: moderate heat; ReC: recommended comfort; MiC: mild cold; and MoC: moderate cold.

According to the equations for the treatments moderate heat, recommended comfort, mild cold, and moderate cold, for the age interval of the studied birds, each increase of one day in the bird life led to an increase in body weight of 9.6092, 9.9997, 9.3649, and $9.4652 \mathrm{~g}$, respectively, demonstrating that the treatments recommended comfort and moderate heat provided higher increases in the values of body weight.

Moraes et al. (2002) assessed the development of broiler chicks from 1 to 7 days of age reared at ambient temperatures of 20,25 , and $35{ }^{\circ} \mathrm{C}$ and observed that 35 ${ }^{\circ} \mathrm{C}$ provided a significantly lower body weight when compared to the other thermal environments. These values differ, in part, from those found in our research, in 
which body weight values of birds exposed to the treatment moderate heat $\left(38.0{ }^{\circ} \mathrm{C}\right)$ and comfort recommended in the literature $\left(33.0{ }^{\circ} \mathrm{C}\right)$, with temperatures close to those used by these author, were superior to environments with the treatments mild cold $\left(28.0^{\circ} \mathrm{C}\right)$ and moderate cold $\left(25.0^{\circ} \mathrm{C}\right)$.

\section{Feed intake}

Table 5 shows the feed intake (FI) of Lohmann LSL Lite line chicks in the period from one to 42 days of age submitted to the treatments moderate heat $(\mathrm{MoH})$, recommended comfort $(\mathrm{ReC})$, mild cold $(\mathrm{MiC})$, and moderate cold (MoC).

TABLE 5. Average values of feed intake (FI) in grams for laying birds from one to 42 days of age for the respective combinations of days and the thermal environments moderate heat $(\mathrm{MoH})$, recommended comfort $(\mathrm{ReC})$, mild cold $(\mathrm{MiC})$, and moderate cold (MoC).

\begin{tabular}{ccccc}
\hline \multirow{2}{*}{ Bird age } & \multicolumn{3}{c}{ FI } & \\
\cline { 2 - 5 } & MoH & ReC & MiC & MoC \\
\hline 8 & $73.78^{\mathrm{a}}$ & $76.43^{\mathrm{a}}$ & $141^{\mathrm{a}}$ & $75.20^{\mathrm{a}}$ \\
15 & $140.83^{\mathrm{a}}$ & $147.85^{\mathrm{a}}$ & $1493^{\mathrm{a}}$ & $159.30^{\mathrm{a}}$ \\
22 & $134.96^{\mathrm{a}}$ & $146.71^{\mathrm{a}}$ & $142.78^{\mathrm{a}}$ & $150.28^{\mathrm{a}}$ \\
29 & $171.86^{\mathrm{a}}$ & $178.17^{\mathrm{a}}$ & $271^{\mathrm{a}}$ & $196.86^{\mathrm{a}}$ \\
36 & $288.22^{\mathrm{b}}$ & $266.94^{\mathrm{b}}$ & $275.94^{\mathrm{b}}$ & $304.42^{\mathrm{a}}$ \\
42 & $281.70^{\mathrm{a}}$ & $277.66^{\mathrm{a}}$ & $284.0^{\mathrm{a}}$ & $293.38^{\mathrm{a}}$ \\
\hline
\end{tabular}

Means followed by at least one letter in the row do not differ from each other by the Tukey's test at 5\% probability level.

Feed intake for all treatments in relation to each assessment day differed $(\mathrm{P}<0.05)$ only in birds with 36 days of age, with the treatment moderate cold $\left(17.0^{\circ} \mathrm{C}\right)$ showing a higher feed intake. This result is in accordance with those found by Silva et al. (2009), who assessed the effect of temperature on feed intake for broiler chickens during the initial rearing stage and observed that, when submitted to low temperatures, birds presented a higher feed intake. At low temperatures, the higher feed intake of birds in relation to the recommended comfort indicates the need for higher energy intake for the maintenance of body temperature.
These results are in accordance with those found by Cândido et al. (2016), who assessed the effects of five different thermal environments on the welfare of broiler chickens from one to 21 days and observed that the treatments moderate cold $\left(24^{\circ} \mathrm{C}\right.$ in the first week, $21^{\circ} \mathrm{C}$ in the second week, and $18{ }^{\circ} \mathrm{C}$ in the third week of life) and accentuated cold $\left(21^{\circ} \mathrm{C}\right.$ in the first week, $18{ }^{\circ} \mathrm{C}$ in the second week, and $15^{\circ} \mathrm{C}$ in the third week of life) provided a significantly higher feed intake than the other treatments.

The regression analysis for the feed intake of laying birds for all treatments showed a linear increase $(\mathrm{P}<0.01)$ in feed intake as bird age increased (Table 6 and Figure 3).

TABLE 6. Adjusted regression equations for the variable feed intake (FI) of laying birds from one to 42 days of age as a function of the assessed days for the thermal environments moderate heat $(\mathrm{MoH})$, recommended comfort (ReC), mild cold $(\mathrm{MiC})$, and moderate cold $(\mathrm{MoC})$ and coefficients of determination.

\begin{tabular}{ccc}
\hline Thermal environment & Adjusted equations & $\mathbf{r}^{\mathbf{2}}$ \\
\hline $\mathrm{MoH}$ & $\hat{\mathrm{Y}}=21.4136+6.3347^{* *} \mathrm{D}$ & 0.8943 \\
$\mathrm{ReC}$ & $\hat{\mathrm{Y}}=35.0098+5.8138^{* *} \mathrm{D}$ & 0.9296 \\
$\mathrm{MiC}$ & $\hat{\mathrm{Y}}=32.3925+5.9817^{* *} \mathrm{D}$ & 0.9058 \\
$\mathrm{MoC}$ & $\hat{\mathrm{Y}}=30.1692+6.5686^{* *} \mathrm{D}$ & 0.9047 \\
\hline
\end{tabular}

\footnotetext{
$* * \mathrm{P}<0.01$ by the t-test.
} 


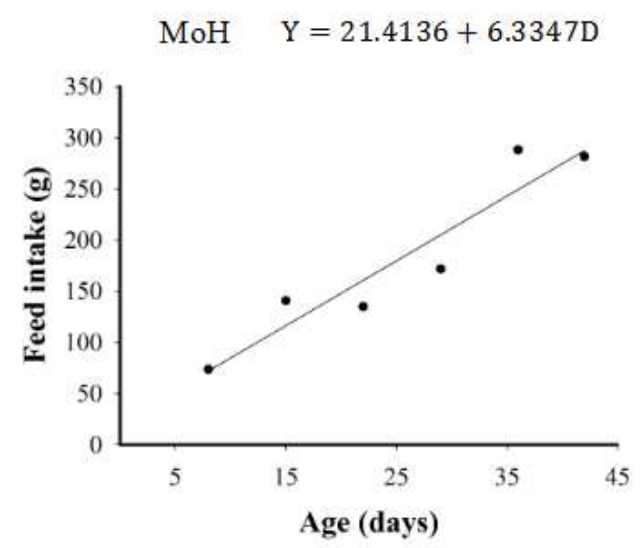

$\mathrm{MiC} \quad \mathrm{Y}=32.3925+5.9817 \mathrm{D}$

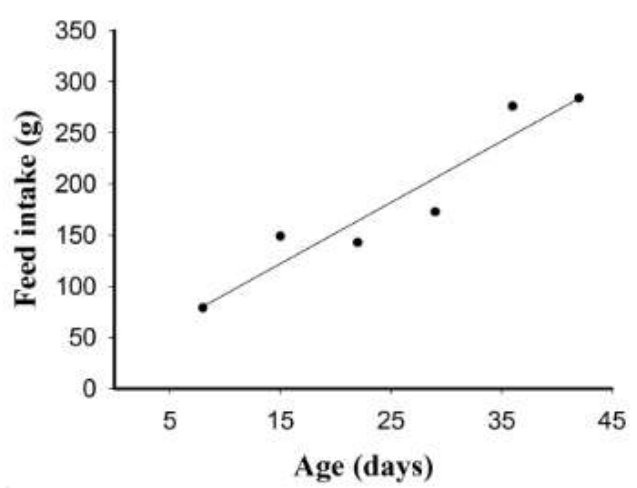

$\operatorname{ReC} \quad \mathrm{Y}=35.0098+5.8138 \mathrm{D}$

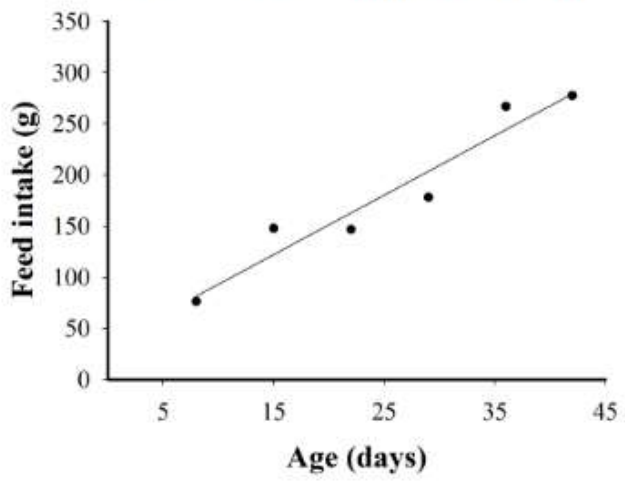

MoC $\quad \mathrm{Y}=30.1692+6.5686 \mathrm{D}$

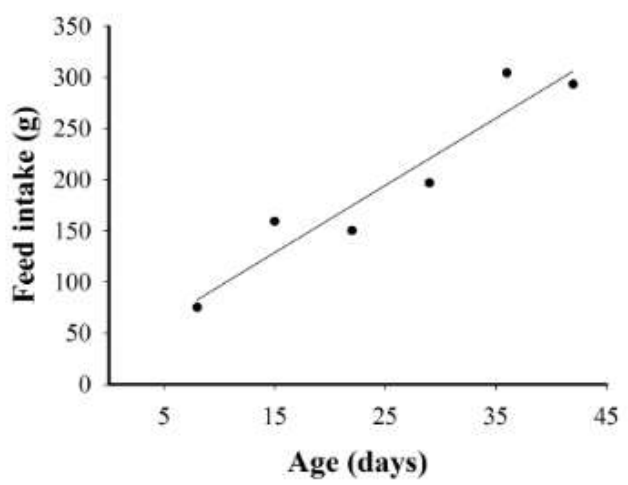

FIGURE 3. Effect of assessment days on feed intake for each thermal environment assessed in laying birds from one to 42 days. MoH: moderate heat; $\mathrm{ReC}$ : recommended comfort; MiC: mild cold; and MoC: moderate cold.

According to the equations found for the treatments moderate heat, recommended comfort, mild cold, and moderate cold, for the age interval of the studied birds, each increase of one day led to an increase of 6.3347 , $5.8138,5.9817$, and $6.5686 \mathrm{~g}$ in feed intake, respectively. Birds submitted to the treatment moderate heat presented an increase in feed intake $8.9 \%$ higher when compared to the treatment comfort recommended by the literature, while the birds submitted to the treatments mild cold and moderate cold showed an increase in feed intake of 2.9 and $12.9 \%$, respectively, when compared to the treatment recommended comfort.

According to Souza et al. (2014), growing animals maintain food intake under cold stress, generating an increase in heat and most of the energy that would be used for tissue accumulation is used for maintenance, worsening performance.
The lowest feed intake was observed for birds submitted to the treatment comfort recommended by the literature. These results differ from those found by Cassuce et al. (2013), who verified a higher feed intake in broiler chickens maintained at ambient temperatures of 31.3 and $27{ }^{\circ} \mathrm{C}$ in the first and second week of life, respectively, which are similar to the values of temperature used in our study for the treatment recommended comfort. These results suggest that laying hens require air temperatures higher than those required by broiler chickens during the first two weeks of life.

\section{Accumulated productive performance of birds up to 42 days of life at each of the different thermal environments}

Table 7 shows the values of accumulated productive performance of birds in the period from one to 42 days of age in each of the different thermal environments.

TABLE 7. Accumulated average values for the parameters final body weight (BW), feed intake (FI), weight gain (WG), and feed conversion (FC) for laying birds during the initial rearing stage (from one to 42 days of age) according to the thermal environments moderate heat $(\mathrm{MoH})$, recommended comfort $(\mathrm{ReC})$, mild cold $(\mathrm{MiC})$, and moderate cold $(\mathrm{MoC})$.

\begin{tabular}{|c|c|c|c|c|c|}
\hline \multirow[b]{2}{*}{ Thermal environment } & \multicolumn{5}{|c|}{$\begin{array}{r}\text { Productive performance at } 42 \text { days of age } \\
\end{array}$} \\
\hline & $\begin{array}{c}\text { BW } \\
\left(\text { g bird }^{-1}\right)\end{array}$ & $\begin{array}{c}\text { FI } \\
(\mathrm{g})\end{array}$ & $\begin{array}{c}\text { WG } \\
\left(\mathrm{g} \mathrm{bird}^{-1}\right)\end{array}$ & FC & $\begin{array}{l}\mathrm{U} \\
(\%)\end{array}$ \\
\hline $\mathrm{MoH}$ & $410.72 \pm 4.8$ & 1091.35 & 367.48 & 2.96 & 81.47 \\
\hline $\mathrm{ReC}$ & $430.42 \pm 3.8$ & 1093.68 & 388.08 & 2.82 & 80.54 \\
\hline $\mathrm{MiC}$ & $409.44 \pm 5.2$ & 1104.18 & 369.76 & 2.98 & 74.07 \\
\hline $\mathrm{MoC}$ & $411.68 \pm 5.4$ & 1179.46 & 370.79 & 3.18 & 58.33 \\
\hline
\end{tabular}


Ambient temperature influences the productive development of birds, altering feed intake and, consequently, weight gain and feed conversion. The final performance of laying birds at 42 days of age, represented by weight gain, feed conversion, final weight, and uniformity, was always better in the treatment comfort recommended in the literature when compared to the others. The worst values of feed conversion (FC) for the treatments mild cold and moderate cold occurred due to an increased food intake, which was mainly used for calorie addition and maintenance of homeothermia, not for weight gain.

\section{CONCLUSIONS}

Experiment conduction under controlled environment allowed assessing the influence of air temperature on the productive responses of birds during the assessments weeks.

The performance of laying birds during the initial stage of rearing (from one to 42 days of life), represented by weight gain, feed conversion, and final weight is better for the temperatures of $33,28,26,23,19$, and $19{ }^{\circ} \mathrm{C}$ (for the first, second, third, fourth, fifth, and sixth week of birds, respectively). These values corresponded, during the experiment, to the BGHI values of $82.7,76.9,72.4$, $70.7,66.4$, and 66, indicating that these temperatures provide better thermal comfort and welfare to laying birds at this age.

\section{ACKNOWLEDGMENTS}

This study was carried out with the support of the Brazilian National Council for Scientific and Technological Development (CNPq). This study was financed in part by the Coordenação de Aperfeiçoamento de Pessoal de Nível Superior - Brasil (CAPES) - Finance Code 001. FAPEMIG and LOHMANN DO BRASIL.

\section{REFERENCES}

Albino LFT, Carvalho BD, Maia R, Barros V (2014) Galinhas Poedeiras Criação e Alimentação. Aprenda Fácil, $376 \mathrm{p}$.

Almeida EAD, Passini R (2013) Thermal comfort in reduced models of broilers' houses, under different types of roofing materials. Engenharia Agrícola 33(1):19-27.

Buffington DE, Collazo-Arocho A, Canton GH, Pitt D (1981) Black globe humidity index (BGHI) as comfort equation for dairy cows. Transactions of the ASAE 24(3):711-714.

Camerini NL, Silva RC, Nascimento JWB, Oliveira DL, Souza BB (2016) Variação da temperatura superficial de aves poedeiras criadas em dois sistemas de criação utilizando termografia. Agropecuária Científica no Semiárido 12(2):145-152.

Campos AT, Klosowski ES, Sousa FA, Ponciano PF, Navarini FC, Yanagi Junior T (2013) Eficiência de sistema de aquecimento auxiliar para aviários, com base nos índices de conforto térmico. Bioscience Journal 29(3):703-711.

Cândido MGL, Tinôco IFF, Pinto FAC, Santos NT, Roberti RP (2016) Determination of thermal comfort zone for earlystage broilers. Engenharia Agrícola 36(5):760-767.
Cassuce DC, Tinôco IFF, Baêta FC, Zolnier, S, Cecon PR, Vieira MFA (2013) Thermal comfort temperature update for broiler chickens up to 21 days of age. Engenharia Agrícola 33(1):28-36.

Cella PS, Donzele JL, Oliveira RFM, Albino LFT, Ferreira AS, Gomes PC, Valerio SR, Apolônio, LR (2001) Níveis de lisina mantendo a relação aminoacídica para frangos de corte no período de 1 a 21 dias de idade, em diferentes ambientes térmicos. Revista Brasileira de Zootecnia 30(2):433-439.

Costa EMS, Dourado LRB, Merval RR (2012) Medidas para avaliar o conforto térmico em aves. Publicações em Medicina Veterinária e Zootecnia 6(31):1450-1454.

Curi TMRC, Vercellino RA, Massari JM, Souza ZM, Moura DJ (2014) Geoestatística para a avaliação do controle ambiental do sistema de ventilação em instalações comerciais para frangos de corte. Engenharia Agrícola 34(6):1062-1074.

Jácome IMTD, Furtado DA, Leal AF, Silva JHV, Moura JFP (2007) Avaliação de índices de conforto térmico de instalações para poedeiras no nordeste do Brasil. Revista Brasileira de Engenharia Agrícola e Ambiental 11(5):527-531.

Lopes JCO, Ribeiro MN, Lima VBS (2015) Estresse por calor em frangos de corte. Revista Eletrônica Nutri-Time 12(6):4478-4487.

Management Guide Lohmann LSL-Lite (s.d). Available in: http://www.hylinena.com/UserDocs/products/Lohmann_L SL-Lite.pdf. Accessed: Nov 15, 2017.

Menegali I, Tinôco IFF, Carvaho CCS, Souza CF, Martins JH (2013) Comportamento de variáveis climáticas em sistemas de ventilação mínima para produção de pintos de corte. Revista Brasileira de Engenharia Agrícola e Ambiental 17(1):106-113.

Moraes VMB, Malheiros RD, Furlan RL, Bruno LDG, Malheiros EB, Macari M (2002) Effect of environmental temperature during the first week of brooding period on broiler chick body weight, viscera and bone development. Revista Brasileira de Ciência Avícola 4(1):19-26.

Ponciano PF, Lopes MA, Yanagi Junior T, Ferraz GAS (2011) Análise do ambiente para frangos por meio da lógica fuzzy: uma revisão. Archivos de Zootecnia 60(1):1-13.

Regmi P, Deland TS, Steibel JP, Robison CI, Haut RC, Orth MW, Karcher DM (2015) Effect of rearing environment on bone growth of pullets. Poultry Science 94(3):502-511.

SAEG - Sistema para Análises Estatísticas (2007) Versão 9.1. Fundação Arthur Bernardes.

Santos GB, Sousa IF, Brito CO, Santos VS, Barbosa RJ, Soares C (2014) Estudo bioclimático das regiões litorânea, agreste e semiárida do estado de Sergipe para avicultura de corte e postura. Ciência Rural 44(1):123-128. 
Schiassi L, Júnior TY, Reis GM, Abreu LH, Campos AT, Castro JDO (2015) Modelagem Fuzzy aplicada na avaliação do desempenho de frangos de corte. Revista Brasileira de Engenharia Agricola e Ambiental-Agriambi 19(2):140-146.

Silva VK, Silva JDT, Gravena RA, Marques RH, Hada FH, Moraes VMB (2009) Desempenho de frangos de corte de 1 a 21 dias de idade alimentados com rações contendo extrato de leveduras e prebiótico e criados em diferentes temperaturas. Revista Brasileira de Zootecnia 38(4):690-696.
Souza MS, Tinôco IFF, Amaral AG, Inoue KRA, Barreto LS, Savastano Junior H, Souza CF, Paula MO (2014) Thermal comfort zones for starter meat-type qualis. Brazilian Journal of Poultry Science 16(3):265-272.

Tinôco IFF (2001) Avicultura Industrial: Novos conceitos de materiais, concepções e técnicas construtivas disponíveis para galpões avícolas Brasileiros. Revista Brasileira de Ciência Avícola 3(1):1-26. 